\title{
The Effect of Foliar Potassium and Seaweed Products in Combination with a Leonardite Fertigation Product on Flame Seedless Grape Quality
}

\author{
J. Strydom*
}

Viticulture Division, ARC Infruitec-Nietvoorbij ${ }^{1}$, Stellenbosch, South Africa

Submitted for publication: March 2014

Accepted for publication: May 2014

Key words: Berry size, colour, ripening, total soluble solids, total titratable acidity

\begin{abstract}
Berry colour and size are important factors determining Flame Seedless quality. Supplementary to standard cultivation, foliar application of potassium $(\mathrm{K})$ and seaweed or soil application of vegetable extracts affect grape quality. The purpose of this trial was to determine if combined product application (CPA) of K, seaweed and leonardite (organic material of vegetable origin) can improve Flame Seedless grape colour, berry size and composition. This study was conducted on Flame Seedless in the Berg River Valley in two seasons. In 2011/2012, leonardite was applied through fertigation six, four and three weeks before harvest, while $\mathrm{K}$ and seaweed were applied as foliar sprays four and three weeks before harvest. In 2012/2013, all products were applied eight and six weeks before harvest. Treatments included (1) control (ethephon/ ethephon and abscisic acid - ABA); (2) CPA with ethephon/ethephon and ABA (CPA-plus); and (3) CPA without ethephon/ethephon and ABA (CPA-minus). All vines received standard gibberellic acid treatments. Berry quality was determined. In 2011/2012, CPA-minus reduced anthocyanin concentration significantly compared to the control. CPA-plus increased berry diameter significantly compared to the control on the first harvest date in 2012/2013. Compared to the control, CPA-plus significantly increased total soluble solids (TSS) on all harvest dates in 2011/2012, and on the first harvest date of 2012/2013. Compared to the control, CPA-plus did not improve colour, but it retarded total titratable acidity breakdown in both seasons. Ethephon/ethephon and ABA must be applied for acceptable colour. The consistent effect on TSS shows the ability of CPA-plus to enhance Flame Seedless ripening.
\end{abstract}

\section{INTRODUCTION}

Flame Seedless is the earliest ripening red seedless cultivar in South Africa and, in the 2011/2012 season, it contributed 9\% to total exports (Anon., 2012). Under high temperature conditions, Flame Seedless tends to develop insufficient colour (Weinberger \& Harmon, 1974). Flame Seedless colour is an important quality attribute, because it determines visual acceptability. Berry size contributes to yield and, if the diameter of Flame Seedless berries is increased from $17 \mathrm{~mm}$ to $18 \mathrm{~mm}$, the harvest may increase by $21 \%$ (G.G. van der Merwe, personal communication, 2012). Plant bioregulators (PBRs) such as gibberellic acid $\left(\mathrm{GA}_{3}\right)$ have a berry-enlarging effect (Wolf \& Loubser, 1992), whereas exogenous abscisic acid (ABA; Wheeler et al., 2009) and ethylene (Human \& Bindon, 2008) are used to enhance table grape colour. Ethylene must be used cautiously due to strict regulations set by the European Food Safety Authority (EFSA) for maximum allowed residue levels (Anon., 2009).
Therefore, there is a need to investigate the use of alternative cultivation practices, including potassium $(\mathrm{K})$ and seaweed foliar products, in combination with leonardite (organic fossil material of vegetable origin) fertigation, to improve table grape quality.

It was found that products supplementary to PBRs, such as soil-applied vegetable extracts, increase total anthocyanins of red grapes (Parrado et al., 2007). Ascophyllum nodosum seaweed extract applied at $15 \mathrm{~cm}$ to $20 \mathrm{~cm}$ shoot length, prebloom and at pea berry size, improved the brightness and redness of Trakya Ilkeren grapes (Kok et al., 2010). Redglobe grapes, supplemented with a $1.5 \%$ Ecklonia maxima extract solution at $12 \mathrm{~mm}$ and $16 \mathrm{~mm}$ berry diameter, tended to produce a higher percentage of bunches with a darker colour (Avenant \& Avenant, 2006). Supplementary foliar sprays with seaweed products can also improve berry size, yield and grape quality (Norrie et al., 2002; Norrie \& Keathley, 2006). Studies have shown that bunch applications of $\mathrm{K}$,

\footnotetext{
${ }^{1}$ The Fruit, Vine and Wine Institute of the Agricultural Research Council
} 
in addition to standard cultivation practices, lead to earlier maturity and improved grape colour (Thakur et al., 2008). Similarly, Topalović et al. (2011) reported an increase in total sugars and total anthocyanins with foliar applications of $\mathrm{P}$ and $\mathrm{K}$

Local studies by Cosmocel Specialised Nutrition (Pty) Ltd with other table grape cultivars in the Lower Orange River region showed that table grapes benefit in terms of colour, size and increased total soluble solids (TSS) with the use of a leonardite fertigation product in combination with a foliar nutrient containing $\mathrm{K}$, as well as a foliar seaweed product (A Bender, personal communication, 2011). These claims need to be independently verified under local conditions before final recommendations can be made.

The objectives of this study were to determine the effect of combined application of one leonardite fertigation product, a foliar $\mathrm{K}$ product and foliar seaweed product on berry colour, berry size, TSS and total titratable acidity of Flame Seedless grapes in the Berg River Valley.

\section{MATERIALS AND METHODS}

The trial was conducted on Flame Seedless (Vitis vinifera L.) grafted onto Ramsey (Vitis champinii) in two consecutive seasons (2011/2012 and 2012/2013). The trial site was on Onverwags farm $\left(33^{\circ} 8^{\prime} \mathrm{S}, 18^{\circ} 59^{\prime} \mathrm{E}\right)$ near Porterville, in the Berg River Valley region in the Western Cape Province of South Africa. The drip-irrigated vines were spaced $1.78 \mathrm{~m}$ x $3.0 \mathrm{~m}$ on a sandy soil with 70 to $75 \%$ river stones, and trained onto a gable trellis system.

Mean monthly temperature and rainfall data (2011/2012 and 2012/2013) were obtained from an automatic weather station near Porterville in the Berg River Valley region (Fig. 1).

Standard viticultural practices for cultivar and region were applied according to guidelines for the preparation of export grapes (Greyling, 2007). In both seasons, the vines were girdled at $4 \mathrm{~mm}$ to $5 \mathrm{~mm}$ berry diameter. In 2011/2012, berry-thinning sprays (5 ppm gibberellic acid - $\mathrm{GA}_{3}$, $400 \mathrm{~g} / \mathrm{kg}$ gibberellins active ingredient, applied at $80 \%$ and $100 \%$ flowering) and berry enlargement sprays (15 ppm GA applied at $6 \mathrm{~mm}$ to $7 \mathrm{~mm}$ and $7 \mathrm{~mm}$ to $8 \mathrm{~mm}$ berry diameter) were applied to all vines. In 2012/2013, all vines received $\mathrm{GA}_{3}$ thinning (5 ppm GA applied at $80 \%$ flowering and $80 \%$ flowering plus three days) and berry enlargement (20 ppm $\mathrm{GA}_{3}$ applied at $7 \mathrm{~mm}$ to $8 \mathrm{~mm}$ berry diameter and $20 \mathrm{ppm}$ $\mathrm{GA}_{3}$ applied at $8 \mathrm{~mm}$ to $9 \mathrm{~mm}$ berry diameter) sprays.

The products used (Table 1) were a leonardite (organic fossil material of vegetable origin) fertigation product $\left(\right.$ Frute ${ }^{\circledR}$ ), in combination with a foliar nutrient containing potassium $(\mathrm{K})$ (Amino $\mathrm{PK}^{\circledR}$ ), as well as a foliar seaweed product (Biocel), all supplied by Cosmocel Specialised Nutrition (Pty) Ltd (P O Box 962, Tzaneen, 0850).

In both seasons, the trials were laid out as a completely randomised design. In 2011/2012, there were three treatments (Table 2), replicated seven times, consisting of a control (200 ppm ethephon, $480 \mathrm{~g} / \mathrm{L}$ active ingredient, applied at 5\% véraison and $20 \%$ véraison), combined product application (CPA) of leonardite, seaweed and $\mathrm{K}$ with ethephon (200 ppm ethephon, applied at 5\% véraison and $20 \%$ véraison; CPAplus) and CPA without ethephon (CPA-minus). In 2012/2013, two treatments (Table 3) were replicated ten times. The treatments were a control, consisting of $250 \mathrm{ppm}$ ethephon plus $100 \mathrm{ppm} S$-abscisic acid ( $S$-ABA), $200 \mathrm{~g} / \mathrm{kg}$ active ingredient, applied at $10 \%$ véraison, followed by $200 \mathrm{ppm}$ ethephon plus $100 \mathrm{ppm} S$-ABA three days later and CPA with $250 \mathrm{ppm}$ ethephon plus $100 \mathrm{ppm} S$-ABA, applied at $10 \%$ véraison, followed by $200 \mathrm{ppm}$ ethephon plus $100 \mathrm{ppm}$ $S$-ABA three days later (CPA-plus). An experimental unit consisted of five vines. The three vines in the middle were used as data vines and the vines on the outside served as buffer vines.

In 2011/2012, leonardite was applied six, four and three weeks before harvest, and the two foliar products were applied four and three weeks before harvest. In 2012/2013, all products were applied eight weeks before harvest and repeated six weeks before harvest to coincide with the cell division stage of berry growth, as opposed to véraison during the previous season. Foliar treatments on Flame Seedless were applied as leaf and bunch-directed sprays to ensure full coverage to the point of run-off. The leonardite was applied with a measuring jug on the soil surface right above the vine roots.

According to the maturity indices of the Department of Agriculture, Forestry and Fisheries (DAFF), the minimum total soluble solids (TSS) for Flame Seedless is $15^{\circ}$ Brix (DAFF, 1990). When average berry TSS for Flame Seedless reached minimum export requirements, the harvest-ready bunches were harvested. In 2011/2012, harvesting and sampling were done on 10 and 17 January, while sampling only was also done on 24 January. In 2012/2013, harvesting and sampling were done on 15 and 22 January. On each sampling date, 100 berries were sampled randomly from each experimental unit. Harvest-ready bunches from each of the data vines of each experimental unit were harvested and weighed. On the second harvest date, bunches were packed for cold storage. Bunches were individually packed in polycoats inside $4.5 \mathrm{~kg}$ closed-top cartons lined with a perforated plastic bag. A UVASYS ${ }^{\circledR}$ dual release sulphur dioxide $\left(\mathrm{SO}_{2}\right)$ generator sheet (Grapetek, South Africa) was positioned on top of the grapes in each carton.

In the 2011/2012 season, 30 leaves per experimental unit were sampled on the first harvest date to determine the nutrient status of the vines at harvest. Leaves opposite bunches were selected and the petioles and leaf blades were separated immediately. The leaves and petioles were oven dried and extracted with $1.0 \mathrm{M} \mathrm{KCl}$, and analysed for $\mathrm{N}$, $\mathrm{P}, \mathrm{K}, \mathrm{Ca}, \mathrm{Mg}, \mathrm{Na}, \mathrm{Mn}, \mathrm{Fe}, \mathrm{Cu}, \mathrm{Zn}$ and $\mathrm{B}$ by an accredited commercial laboratory according to the standard methods of Campbell and Plank (1998) and Miller (1998).

The sampled berries from each date were used to determine berry mass. From these berry samples, 30 randomly selected berries were used to determine berry diameter, and 10 randomly selected berries were used to determine berry colour with a Konica Minolta CR 400 chromameter. The CIELAB colour space (McGuire, 1992) was used, with L* indicating lightness, and $\mathrm{a}^{*}$ and $\mathrm{b}^{*}$ indicating the colour scale. The values $\mathrm{L}^{*}, \mathrm{a}^{*}$ and $\mathrm{b}^{*}$ describe a uniform threedimensional colour space, where the $\mathrm{L}^{*}$ value corresponds to a dark-bright scale ( 0 , black; 100 , white), the $a^{*}$ value to a green-red scale (negative value, greenness; positive, 

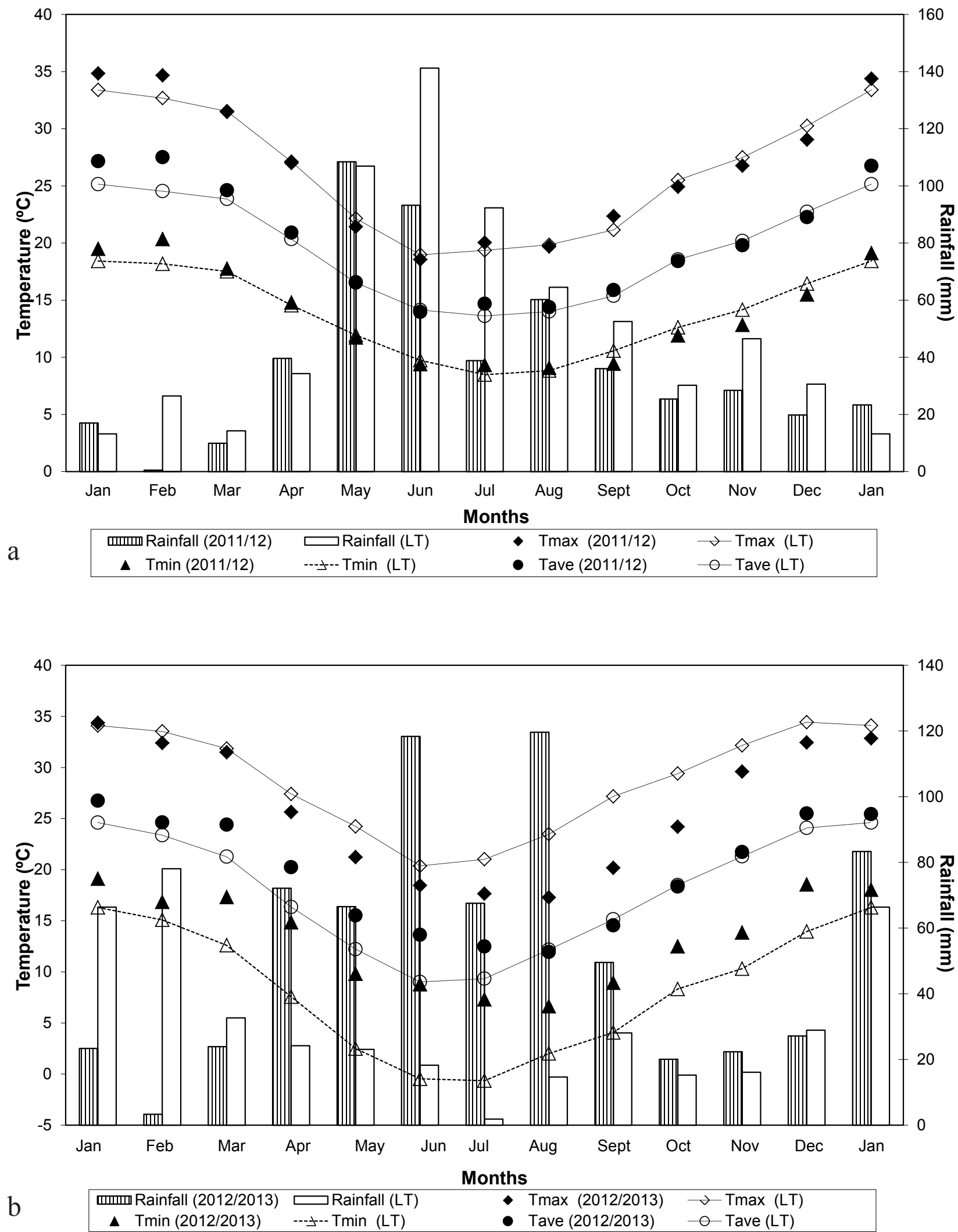

FIGURE 1

Mean monthly (January to January) and long-term (LT - 2006 to 2012) temperature and rainfall at Onverwags*, South Africa (ARC-ISCW, 2013) for (a) 2011/2012 and (b) 2012/2013. (Tmax = mean monthly maximum temperature; Tmin $=$ mean monthly minimum temperature; Tave = average temperature). ${ }^{*}$ Climatic data was obtained from a weather station at Porterville (situated approximately $10 \mathrm{~km}$ from the farm). 
redness) and the $\mathrm{b}^{*}$ value to a blue-yellow scale (negative value, blueness; positive, yellowness). Fifty fresh berries of the same samples were used for the determination of TSS, total titratable acidity (TTA) and anthocyanin concentration. TSS was determined with a digital hand-held refractometer (Atago dbx-30) and expressed as ${ }^{\circ}$ Brix. TTA (g/L) was determined by titration of a $50 \mathrm{~mL}$ filtered juice sample with $0.333 \mathrm{~N} \mathrm{NaOH}$ to a $7 \mathrm{pH}$ end-point using an automatic titrator (Mettler Toledo DL15). The anthocyanin concentration of whole berries was determined by spectrophotometry (Thermospectronic He $\lambda$ ios Gamma), according to the method of Iland et al. (2000), and expressed as $\mathrm{mg} / \mathrm{g}$ fresh

TABLE 1

Composition of the leonardite, potassium and seaweed products.

\begin{tabular}{|c|c|c|c|}
\hline Product type & Tradename & Chemical composition & Content \\
\hline \multirow[t]{3}{*}{ Leonardite fertigation } & Frutex $^{\circledR}$ & Potassium $(\mathrm{K})$ & $142 \mathrm{~g} / \mathrm{kg}$ \\
\hline & & Humic and fulvic acids & $300 \mathrm{~g} / \mathrm{kg}$ \\
\hline & & Organic extracts of vegetable origin & $300 \mathrm{~g} / \mathrm{kg}$ \\
\hline \multirow[t]{4}{*}{ Foliar Potassium } & Amino $\mathrm{PK}^{\circledR}$ & Phosphorous (P) & $140 \mathrm{~g} / \mathrm{kg}$ \\
\hline & & Potassium (K) & $442 \mathrm{~g} / \mathrm{kg}$ \\
\hline & & L-amino acids & $30 \mathrm{~g} / \mathrm{kg}$ \\
\hline & & Organic extracts & $20 \mathrm{~g} / \mathrm{kg}$ \\
\hline \multirow[t]{10}{*}{ Foliar seaweed } & Biocel & Organic extracts from biological fermentation processes & $112 \mathrm{~g} / \mathrm{L}$ \\
\hline & & Nitrogen $(\mathrm{N})$ & $15 \mathrm{~g} / \mathrm{L}$ \\
\hline & & Phosphorous (P) & $5.8 \mathrm{~g} / \mathrm{L}$ \\
\hline & & Potassium $(\mathrm{K})$ & $11.1 \mathrm{~g} / \mathrm{L}$ \\
\hline & & Calcium (Ca) & $2.0 \mathrm{~g} / \mathrm{L}$ \\
\hline & & Magnesium (Mg) & $4.0 \mathrm{~g} / \mathrm{L}$ \\
\hline & & Copper $(\mathrm{Cu})$ & $13.3 \mathrm{~g} / \mathrm{L}$ \\
\hline & & Iron $(\mathrm{Fe})$ & $17.2 \mathrm{~g} / \mathrm{L}$ \\
\hline & & Manganese (Mn) & $17.0 \mathrm{~g} / \mathrm{L}$ \\
\hline & & Zinc $(\mathrm{Zn})$ & $33.0 \mathrm{~g} / \mathrm{L}$ \\
\hline
\end{tabular}

TABLE 2

Combined product application (CPA) treatments applied to Flame Seedless grapes in the 2011/12 season.

\begin{tabular}{lcccc}
\hline${ }^{1}$ Treatment & Product and dosage & & \\
\cline { 2 - 5 } & ${ }^{3}$ Leonardite fertigation $(\mathrm{kg} / \mathrm{ha})$ & ${ }^{4}$ Foliar K $(\mathrm{kg} / \mathrm{ha})$ & ${ }^{4}$ Foliar seaweed $(\mathrm{mL} / \mathrm{ha})$ & Ethephon $(\mathrm{ppm})$ \\
\hline${ }^{2}$ Control & 0 & 0 & 0 & $200+200$ \\
CPA-minus & 3 & 3 & 500 & 0 \\
${ }^{2}$ CPA-plus & 3 & 3 & 500 & $200+200$ \\
\hline
\end{tabular}

${ }^{1}$ All treatments received recommended gibberellic acid application

${ }^{2}$ Recommended ethephon application

${ }^{3}$ Applied 6, 4 \& 3 weeks before the first harvest, total application volume $4000 \mathrm{~L} / \mathrm{ha}$

${ }^{4}$ Applied 4 \& 3 weeks before the first harvest, total application volume $1000 \mathrm{~L} / \mathrm{ha}$

TABLE 3

Combined product application (CPA) treatments applied to Flame Seedless grapes in the 2012/13 season.

\begin{tabular}{lccc}
\hline${ }^{1}$ Treatment & Product and dosage & & \\
\hline & ${ }^{2}$ Leonardite fertigation ${ }^{a}(\mathrm{~kg} / \mathrm{ha})$ & ${ }^{2}$ Foliar K $^{b}(\mathrm{~kg} / \mathrm{ha})$ & ${ }^{2}$ Foliar seaweed $^{b}(\mathrm{~mL} / \mathrm{ha})$ \\
\hline Control & 0 & 0 & 0 \\
CPA-plus & 5 & 3 & 500 \\
\hline
\end{tabular}

${ }^{1}$ All treatments received recommended gibberellic acid and Abscisic Acid plus ethephon application

${ }^{2}$ Applied 8 \& 6 weeks before first harvest

${ }^{a}$ Total application volume $4000 \mathrm{~L} / \mathrm{ha}$

${ }^{b}$ Total application volume $1000 \mathrm{~L} / \mathrm{ha}$ 
berry weight (FW).

After four weeks in cold storage at $-0.5^{\circ} \mathrm{C}$, followed by one week at $7.5^{\circ} \mathrm{C}$, evaluations for cold storage defects (loose berries, $\mathrm{SO}_{2}$ damage, berry splitting, decay, soft tissue breakdown and bruises) were carried out. Ten randomly-sampled berries from each carton were used to determine berry firmness with the ISICUDISI Grape and Soft Fruit Compression Tester (Central Electronic Services, Stellenbosch University). The force needed to depress the probe $1 \mathrm{~mm}$ when applied to the berry skin surface, without penetrating the skin, was expressed as g. High values indicate firmer berries.

For all the data, the Shapiro-Wilk test was performed to test for non-normality (Shapiro \& Wilk, 1965). Fisher's least significant differences (LSD) were calculated at a 5\% significance level, to facilitate comparison between the treatment means (Ott \& Longnecker, 2001).

\section{RESULTS AND DISCUSSION}

The CIELAB colour variables are shown in Table 4. In 2011/2012, L* did not show any significant differences between the different treatments, whereas a decreased $\mathrm{L}^{*}$ indicated a darker colour on the second harvest date in 2012/2013 where CPA-plus was applied. Compared to the control, a* obtained on the third sampling date of 2011/2012 increased significantly with CPA-minus and CPA-plus. This implies that, compared to the control, the colour was more towards the red spectrum. Compared to the control, CPAminus significantly increased the $\mathrm{b}^{*}$ values measured on all three sampling dates in 2011/2012, indicating a colour spectrum more towards yellow. In 2011/2012, CPA-minus decreased anthocyanin concentration significantly compared to the control (Table 4). In both seasons the anthocyanin concentration obtained with CPA-plus did not differ significantly from the control.

No reference could be found regarding the use of a leonardite fertigation or similar vegetable extract products combined with seaweed extract and $\mathrm{K}$ products. Only references reporting on the effects of the separate use of a vegetable extract (Parrado et al., 2007), seaweed (Kok et al., 2010; Strydom, 2013) and K (Thakur et al., 2008; Mohsen, 2011) on grape colour are available. It therefore is difficult to compare the findings of this study with those obtained in other studies. The significantly lower $\mathrm{L}^{*}$ value obtained with CPA-plus compared to the control on the second harvest date in 2012/2013 is similar to the lower L* values for Tempranillo juice from vines that received a soil application of vegetable extract (Parrado et al., 2007). On the other hand, foliar application of a seaweed extract to Trakya Ilkeren grapes increased the $\mathrm{L}^{*}$ of the grape pulp of treated grapes (Kok et al., 2010). Increases in $\mathrm{a}^{*}$ and $\mathrm{b}^{*}$ values, as obtained in this study, were also found when seaweed extract was applied to Trakya Ilkeren grapes (Kok et al., 2010). The significant decrease in anthocyanin concentration caused by CPAminus compared to the control in 2011/2012 is in contrast with a study where soil applications of a vegetable extract to Tempranillo vines (Parrado et al., 2007) increased total anthocyanins. It is also in contrast with studies where foliar applications of seaweed extract to Flame Seedless (Strydom, 2013) and foliar applications of $\mathrm{K}$ to Crimson Seedless

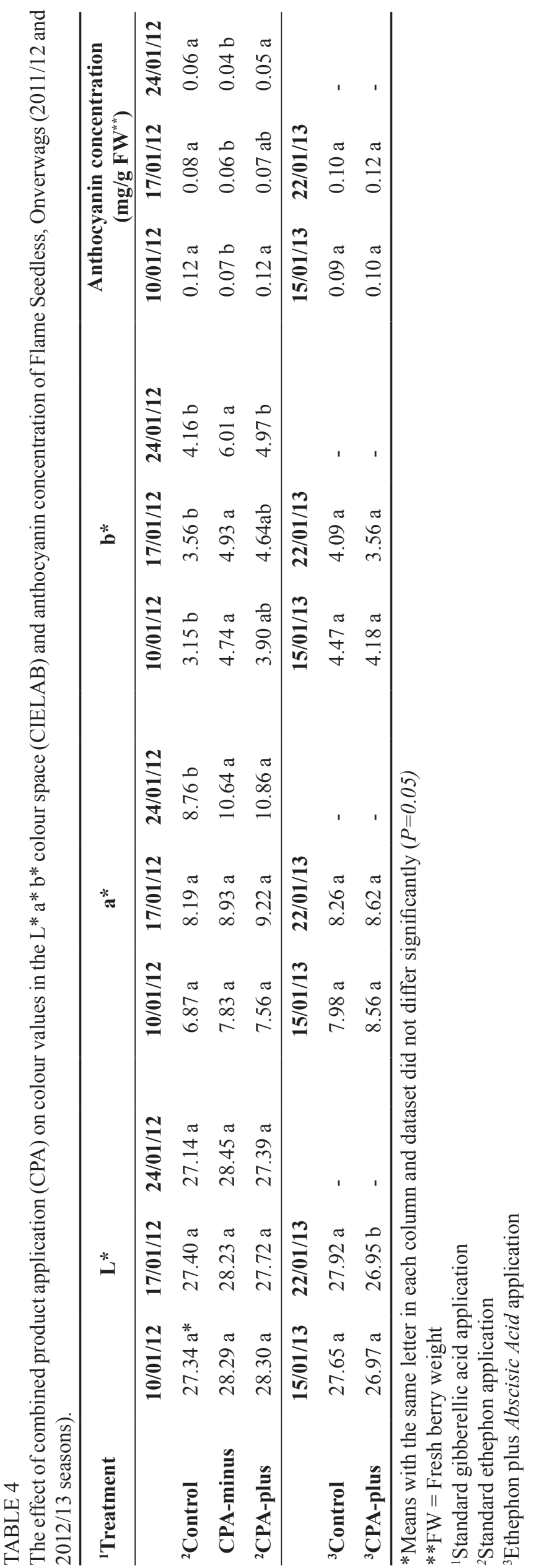


(Mohsen, 2011) increased anthocyanin concentration. It was also found that foliar sprays with a liquid mineral fertiliser containing $\mathrm{P}$ and $\mathrm{K}$ increased total anthocyanins of Cardinal (Topalović et al., 2011).

It is important to emphasise that the current study cannot be compared to other studies (Parrado et al., 2007; Kok et al., 2010, Mohsen, 2011; Topalović et al., 2011; Strydom, 2013) because, amongst others, the product composition (Table 1) and product combinations (Tables 2 and 3 ) were different. Furthermore, the cultivar used in this study was Flame Seedless, and its response to CPA cannot be compared to the response of Tempranillo (Parrado et al., 2007), Crimson Seedless (Mohsen, 2011), Cardinal (Topalović et al., 2011) and Trakya Ilkeren (Kok et al., 2010). The timing of product application, as well as the number of applications in this study, does not correspond to that in other studies (Parrado et al., 2007; Kok et al., 2010, Mohsen, 2011; Topalović et al., 2011; Strydom, 2013). The nutritional status of the vines prior to the application of products must be considered when interpreting the current results compared to those of Mohsen (2011). Mohsen (2011) does not indicate whether the vine nutritional status was determined before $\mathrm{K}$ application. Although macro-elements are not easily altered with foliar sprays (Christensen, 2005), Mohsen (2011) found that the K content of berries at harvest was significantly increased with $\mathrm{K}$ spray applications. It is possible that foliar $\mathrm{K}$ application to the vines in the study of Mohsen (2011) alleviated a possible $\mathrm{K}$ deficiency. Due to the physiological-biochemical role of $\mathrm{K}$ (Clarkson \& Hanson, 1980), foliar K application in the study of Mohsen (2011) thus could have contributed to increased anthocyanin concentration. The effect of environmental conditions on grape quality, and especially colour, must also be considered when explaining the differences between the current results and those of previous studies done in Montenegro (Topalović et al., 2011), Egypt (Mohsen, 2011), Turkey (Kok et al., 2010) and Spain (Parrado et al., 2007). Flame Seedless tends to develop insufficient colour in areas with high temperatures (Weinberger \& Harmon, 1974), such as the area near Porterville. At temperatures above $30^{\circ} \mathrm{C}$, anthocyanin biosynthesis is reduced (Mori et al., 2005) and anthocyanin pigments are degraded (Mori et al., 2007). During the ripening period of Flame Seedless (December to January), maximum temperatures regularly exceeded $30^{\circ} \mathrm{C}$ in the Berg River Valley region (Fig. 1). Thus, temperature might have contributed to responses in terms of grape colour. Although the virus status of the vines used in this study was not verified, it has to be borne in mind that grapevine leafroll virus infections also affect the anthocyanin content of grape berry skins (Brar et al., 2008).

Berry mass increased significantly by the first harvest date with CPA-minus and CPA-plus in 2011/2012 and with CPA-plus by the first harvest date in 2012/2013 (Table 5). In 2012/2013, CPA-plus increased berry diameter significantly only by the first harvest date (Table 5). CPA-minus resulted in a significant decrease in both berry mass and berry diameter by the third sampling date in 2011/2012. Compared to the control, CPA-minus and CPA-plus increased berry length (Table 5) by the second harvest date in 2011/2012. A previous study showed that a seaweed extract, applied as a supplement, increased grape berry size of Sultanina (Norrie et al., 2002). Studies testing the effect of foliar application of $\mathrm{K}$ showed that, in addition to standard viticultural practices, $\mathrm{K}$ increased the berry weight of Crimson Seedless (Mohsen, 2011) and Perlette (Thakur et al., 2008). However, no references were found for the effect of seaweed and $\mathrm{K}$ products combined.

On the first harvest date in $2011 / 2012$, a significantly lower percentage of bunches (Table 5) were harvested from the CPA-minus treatment and a significantly higher percentage of bunches were left on the vines after the second harvest compared to the other two treatments. In 2012/2013 there was no significant difference in the percentage of bunches harvested or left on the vines between the treatment and control. This is an indication that CPA without ethephon/ ethephon and ABA delay the harvest.

Apart from a treatment effect, practices such as bunch thinning also have an effect on berry size (Petrie $\&$ Clingeleffer, 2006). The effect on berry mass is usually more pronounced when bunch thinning is done during the berry growth stage (Naor et al., 2002). The decreased berry mass and diameter caused by CPA-minus compared to the control (third sampling date of 2011/2012) may be ascribed to decreased allocation of assimilates (Naor et al., 2002), because more bunches were left after the second harvest. However, this might not be the reason for the significant increases that CPA-plus caused in berry mass and diameter as measured on the first harvest date, because the total number of bunches per vine did not differ significantly between the trial vines (data not shown). The difference in bunch mass (Table 5) in 2011/2012 can be attributed to harvest preparation practices and may not be treatment related.

Throughout the 2011/2012 harvest period, as well as on the first harvest date of $2012 / 2013$, TSS was significantly higher in the CPA-minus and CPA-plus treatments compared to the control (Table 5). In both seasons, TTA was significantly higher with CPA-plus treatment on the second harvest date compared to the control (Table 5). In 2011/2012, CPA-plus also resulted in a significantly higher TTA compared to the control on the third sampling date. Avenant et al. (1997) reported no significant effect on the TSS or TTA of Ronelle when three K spray treatments were applied at two-week intervals, starting at $15 \mathrm{~cm}$ shoot length. On the other hand, Thakur et al. (2008) reported significantly higher TSS and significantly lower TTA of Perlette grapes when two K spray treatments were applied one week after berry set and repeated at véraison. Kok et al. (2010) reported significantly higher TTA of Trakya Ilkeren with seaweed applied three times, starting at $15 \mathrm{~cm}$ to $20 \mathrm{~cm}$ shoot length and repeated at pre-bloom and pea berry size.

Petiole analyses at harvest showed that the combination of the leonardite, $\mathrm{K}$ and seaweed products used in this study did not have a significant effect on the macro-elements N, P, $\mathrm{K}, \mathrm{Ca}$ and $\mathrm{Mg}$ (Table 6). This was expected, because macroelements are not easily altered with foliar sprays (Christensen, 2005). Mn content in the petioles of the CPA-plus and CPAminus treatments was significantly higher compared to the control treatment (Table 6). Due to the fact that the seaweed included in CPA contains Mn (Table 1), and that foliar sprays containing $\mathrm{Mn}$ can alleviate deficiencies thereof (Bavaresco et al., 2010), it is possible that the response in Mn content 


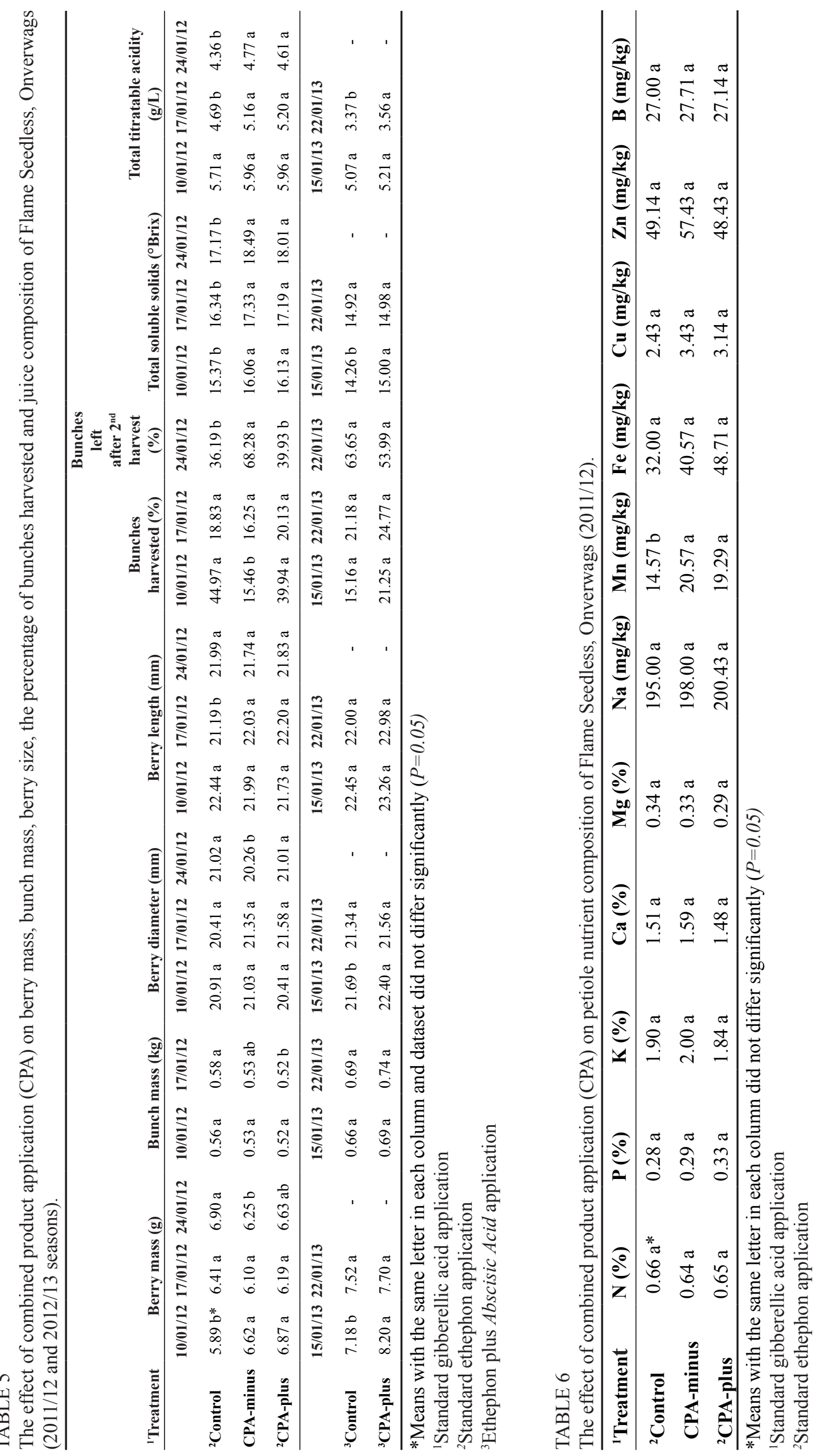


can be ascribed to a Mn deficiency. However, leaf analyses at berry set (data not shown) indicated no deficiencies in macro- or micro-elements. Furthermore, Mn distribution and uptake varies through the season (Pradubsuk \& Davenport, 2011), and the grape berries were not analysed for microelements at harvest. It therefore is uncertain whether the $\mathrm{Mn}$ content of the petiole at harvest was representative of the Mn content of the grapes.

None of the treatments had a significant effect on berry firmness after cold storage and on the percentages of cold storage defects in any of the seasons (data not shown).

\section{CONCLUSIONS}

Combined application of a foliar $\mathrm{K}$ product, a seaweed extract and a leonardite fertigation product, without ethephon/ethephon and ABA, reduced grape colour. CPA without ethephon/ethephon and ABA is not sufficient to mitigate problems with Flame Seedless grape colour, most likely caused by high temperatures in this study. Ethephon or ethephon plus ABA are necessary to produce quality grapes in terms of grape colour. Furthermore, CPA with ethephon/ ethephon and ABA did not improve colour compared to the control (ethephon/ethephon and ABA). Therefore, if future restrictions further limit the use of ethephon, the use of CPA, as described in this study, will not be efficient to overcome problems with Flame Seedless colour. The inconsistent effect on berry mass, diameter and length is not convincing enough to conclude that combined applications of the mentioned products, with or without ethephon/ethephon and ABA, increase berry size.

The combined application of a foliar $\mathrm{K}$ product, a seaweed extract, as well as a leonardite fertigation product, with ethephon/ethephon and ABA, was effective to increase TSS significantly in both seasons, showing its ability to enhance the ripening of Flame Seedless. In both seasons, combined application of a foliar K product, a seaweed extract and a leonardite fertigation product with ethephon/ethephon and ABA significantly retarded TTA breakdown and had no negative effect on the firmness and quality of the grapes after cold storage.

Based on the results obtained, combined application of a foliar $\mathrm{K}$ product, a seaweed extract and a leonardite fertigation product with ethephon/ethephon and ABA is effective to enhance the ripening of Flame Seedless under the conditions described in this trial.

Regional and temperature effects must be considered and the same results will not necessarily be obtained in areas with lower or higher temperatures. The consistency of the products must also be borne in mind. It therefore is recommended that the same products be tested in other cultivation areas, with different temperature conditions, and on other cultivars. Soil analyses, to determine the effect of the fertigation product on soil nutrient status, as well as fruit analyses, to determine the nutrient status of the grape berry as a result of combined application, are also recommended.

\section{LITERATURE CITED}

Anon., 2009. Review of the existing maximum residue levels (MRLs) for ethephon on request of EFSA. EFSA Journal 7, 1347. doi:10.2903/j. efsa.2009.1347.

Anon., 2012. Statistical booklet 2012. South African Table Grape Industry. Available: http://satgi.co.za/pages/Industry-Info/Statistical-Booklet [accessed 02/10/2013]

ARC-ISCW, 2013. Private Bag X79, Pretoria, South Africa, 0001.

Avenant, J.H. \& Avenant, E., 2006. Effect of gibberellic acid and CPPU on colour and berry size of 'Redglobe' grapes on two soil types. Acta Hort. 727, 371-379.

Avenant, E., Avenant, J.H. \& Barnard, R.O., 1997. The effect of three rootstock cultivars, potassium soil applications and foliar sprays on yield and quality of Vitis vinifera L. cv. Ronelle in South Africa. S. Afr. J. Enol. Vitic. 18, 31-38.

Bavaresco, L., Gatti, M. \& Fregoni, M., 2010. Nutritional deficiencies. In: Delrot, S., Medrano, H., Or, E., Bavaresco, L. \& Grando, S. (eds). Methodologies and results in grapevine research. Springer, New York. pp. 165-192.

Brar, H.S., Singh, Z., Swinny, E. \& Cameron, I., 2008. Girdling and grapevine leafroll associated viruses affect berry weight, colour development and accumulation of anthocyanins in 'Crimson Seedless' grapes during maturation and ripening. Plant Sci. 175, 885-897.

Campbell, C.R. \& Plank, C.O., 1998. Preparation of plant tissue for laboratory analysis. In: Kaira, Y.P. (ed.). Handbook of reference methods for plant analysis. Boca Raton, CRC Press. pp. 37-49.

Christensen, L.P. 2005. Foliar fertilization in vine mineral nutrition management programs. In: Christensen, L.P. \& Smart, D.R. (eds). Proc. Soil Environ. Vine Mineral Nutr. Symp. American Society for Enology and Viticulture, Davis, CA. pp. 83-90.

Clarkson, D.T. \& Hanson, J.B., 1980. The mineral nutrition of higher plants. Ann. Rev. Plant Physiol. 31, 239-298.

DAFF (Department of Agriculture, Forestry \& Fisheries), 1990. Export standards and requirements for table grapes. Directorate Food Safety and Quality Assurance, Private Bag X343, Pretoria, 0001, South Africa.

Greyling, M. (ed.) 2007. Guidelines for preparing export table grapes. Capespan Ltd., Bellville.

Human, M.A. \& Bindon, K.A., 2008. Interactive effect of ethepon and shading on the anthocyanin composition of Vitis vinifera L. cv. Crimson Seedless. S. Afr. J. Enol. Vitic. 29, 50-58.

Iland, P.G., Ewart, A., Sitters, J., Markides, A. \& Bruer, N., 2000. Techniques for chemical analysis and quality monitoring during winemaking. Patrick Iland, Adelaide.

Kok, D., Bal, E., Celik, S., Ozer, C. \& Karauz, A., 2010. The influences of different seaweed doses on table quality characteristics of cv Trakya Ilkeren (Vitis vinifera L.). Bulg. J. Agric. Sci. 16, 429-435.

McGuire, R.G., 1992. Reporting of objective color measurements. HortSci. 27, 1254-1255.

Miller, R.O., 1998. High temperature oxidation: Dry ashing. In: Kalra, Y.P. (ed.). Handbook of reference methods for plant analysis. Boca Raton, CRC Press. pp. 53-56.

Mohsen, A.T., 2011. Attempts to improve the berry quality and storability of grape "Crimson Seedless" with potassium compounds under desert conditions. J. Hort. Sci. \& Ornamen. Plants 3, 75-85. 
Mori, K., Goto-Yamamoto, N., Kitayama, M. \& Hashizume, K., 2007. Loss of anthocyanins in red-wine grape under high temperature. J. Exp. Bot. 58, 1935-1945.

Mori, K., Sugaya, S. \& Gemma, H., 2005. Decreased anthocyanin biosynthesis in grape berries grown under elevated night temperature condition. Scienta Hort. 105, 319-330.

Naor, A., Gal, Y. \& Bravdo, B., 2002. Shoot and cluster thinning influence vegetative growth, fruit yield, and wine quality of 'Sauvignon blanc' grapevines. J. Amer. Soc. Hort. Sci. 127, 628-634.

Norrie, J., Branson, T. \& Keathley, P.E., 2002. Marine plant extracts impact on grape yield and quality. Acta Hort. 594, 315-319.

Norrie, J. \& Keathley, J.P., 2006. Benefits of Ascophyllum nodosum marineplant extract applications to 'Thompson Seedless' grape production. Acta Hort. 727, 243-247.

Ott, R.L. \& Longnecker, M., 2001 ( $5^{\text {th }}$ ed). An introduction to statistical methods and data analysis. Belmont, Duxbury Press.

Parrado, J., Escudero-Gilete, M.L., Friaza, V., García-Martínez, A., González-Miret, M.L., Bautista, J.D. \& Heredia, F.J., 2007. Enzymatic vegetable extract with bioactive components: Influence of fertiliser on the colour and anthocyanins of red grapes. J. Sci. Food Agric. 87, 2310-2318.

Petrie, P.R. \& Clingeleffer, P.R., 2006. Crop thinning (hand versus mechanical), grape maturity and anthocyanin concentration: outcomes from irrigated Cabernet Sauvignon (Vitis vinifera L.) in a warm climate. Aust. J. Grape Wine Res. 12, 21-29.
Pradubsuk, S. \& Davenport, J.R., 2011. Seasonal distribution of micronutrients in mature 'Concord' grape: Boron, iron, manganese, copper, and zinc. J. Amer. Soc. Hort. Sci. 136, 69-77.

Shapiro, S.S. \& Wilk, M.B., 1965. An analysis of variance test for normality (complete samples). Biometrika 52, 591-611.

Strydom, J., 2013. Effect of CPPU ( $N$-(2-chloro-4-pyridinyl)- $N$ '-phenylurea) and a seaweed extract on Flame Seedless, Redglobe and Crimson Seedless grape quality. S. Afr. J. Enol. Vitic. 34, 233-240.

Thakur, A., Arora, N.K., Sidhu, A.S. \& Brar, J.S., 2008. Effect of potassium sprays on the quality of Perlette grapes. Acta Hort. 785, 201-206.

Topalović, A., Slatnar, A., Štampar, F., Knežević, M. \& Veberič, R., 2011. Influence of foliar fertilization with $\mathrm{P}$ and $\mathrm{K}$ on chemical constituents of grape cv. 'Cardinal'. J. Agric. Food Chem. 59, 10303-10310.

Weinberger, J.H. \& Harmon, F.N., 1974. 'Flame Seedless' grape. HortSci. 9,602 .

Wheeler, S., Loveys, B., Ford, C. \& Davies, C., 2009. The relationship between the expression of abscisic acid biosynthesis genes, accumulation of abscisic acid and the promotion of Vitis vinifera L. berry ripening by abscisic acid. Aust. J. Grape Wine Res. 15, 195-204.

Wolf, E.E.H. \& Loubser, J.T., 1992. Gibberellic acid levels and quality effects of gibberellic acid in treated table grapes. S. Afr. J. Enol. Vitic. 13, $57-63$. 